\title{
KELEMBAGAAN REHABILITASI LAHAN DAN KONSERVASI TANAH PADA TINGKAT MIKRO DAS, KABUPATEN DAN PROPINSI DI ERA OTONOMI DAERAH
}

\author{
(Land Rehabilitation and Conservation Institution at Micro Watershed, Regency
} and Province Levels in The Decentralization Era)

Oleh /By

Sulistya Ekawati, Syahrul Donie, S. Andy Cahyono dan Nana Haryanti

\begin{abstract}
Land rehabilitation and conservation was conduct on centralistic basis, however, since decentralization, institution of land rehabilitation and conservation has been restructurized, been given to local authority. Land rehabilitation and conservation became crucial and strategic activities for watershed management. Watershed management should apply on ecosystem approach based on one river, one plan and multi management. It has no administrative border, therefore regency or province crossing watershed needed a specific approach for implementating land rehabilitation and conservation. The objective of this research was to provide an information on institution (variety and working mechanism), and pattern of land rehabilitation and conservation at micro, regency and province levels in the decentralization era. Participation method is used in these research through discussion and deep interview. Result showed that organizations involved in management of land rehabilitation and conservation (based on category of national and regional watershed is same), were conducted by government of province. While management of land rehabilitation and conservation (based on category of micro and local watershed) was conducted by government of regency. The working mechanism of institution involved in land rehabilitation at local, regional and national levels is not running well. The coordination on land rehabilitation and conservation was started on Progo watershed, but its implementation is not running well. Although, The upper, middle and lower regencies of watershed have good commitment, because of their good understanding on its benefit. They are not willing to share the costs of land rehabilitation and conservation activities.
\end{abstract}

Key word: institution, land rehabilitation and conservation, decentralization, various organization, work mechanism

\begin{abstract}
Abstrak
Selama ini penyelenggaraan Rehabilitasi Lahan dan Konservasi Tanah (RLKT) dilakukan secara sentralistik, namun sejak adanya otonomi daerah, kelembagaan RLKT mengalami restrukturisasi, karena kewenangan dan pemanfaatan sumberdaya alam (termasuk penyelenggaraan RLKT) menjadi wewenang daerah. RLKT merupakan salah satu kegiatan pengelolaan DAS yang utama dan strategis. Pengelolaan DAS dilakukan melalui pendekatan ekosistem berdasarkan prinsip satu sungai, satu rencana dan satu pengelolaan. Karena DAS tidak mempunyai batas yang bertepatan (co-incided) dengan batas administrasi, maka untuk DAS lintas kabupaten atau lintas propinsi memerlukan pendekatan khusus dalam penyelenggaraan RLKT. Tujuan kajian adalah menyediakan informasi mengenai kelembagaan (jenis dan mekanisme kerja) serta tata nilai yang ada dalam penyelenggaraan RLKT pada tingkat Mikro DAS, kabupaten dan propinsi di era otonomi daerah. Metode yang dipergunakan adalah dengan pendekatan partisipatif dengan melakukan diskusi dan wawancara secara mendalam kepada partisipan. Hasil kajian menunjukkan bahwa organisasi yang terlibat dalam penyelenggaraan RLKT pada kategori DAS nasional dan regional sama, dilakukan oleh pemerintah propinsi, sedangkan penyelenggaraan RLKT pada kategori DAS lokal dan mikro DAS dilakukan pemerintah
\end{abstract}

Kelembagaan Rehabilitasi Lahan dan Konservasi ......(Sulistiya Ekawati dkk) 
kabupaten. Mekanisme kerja lembaga dalam penyelenggaraan RLKT pada level DAS lokal, regional maupun nasional belum berjalan dengan baik. Koordinasi antar lembaga dalam penyelenggaraan RLKT di DAS Progo sudah mulai dirintis, namun demikian aplikasi lapangan belum berjalan dengan baik.Pandangan dan komitmen kabupaten hulu, tengah dan hilir DAS terhadap RLKT adalah baik, karena mereka sebenarnya sudah memahami manfaat dari pelaksanaan kegiatan RLKT. Walaupun demikian masyarakat di daerah hulu, tengah dan hilir DAS belum bersedia untuk melakukan sharing dalam pembiayaan RLKT.

Kata kunci : kelembagaan, RLKT, otonomi daerah, jenis organisasi, mekanisme kerja

\section{PENDAHULUAN}

Pemahaman kelembagaan sangat beragam, tergantung dari disiplin ilmu dan perspektif dari mana seseorang memandangnya. Definisi yang sederhana dikemukakan oleh Soekanto (1990), yang menyatakan bahwa kelembagaan merupakan suatu sistem norma khusus yang menata suatu rangkaian tindakan berpola guna memenuhi kebutuhan manusia dalam kehidupan bersama. Sedangkan Darmawan (2001) mendefinisikan kelembagaan sebagai organisasi dan pranata yang di dalamnya meliputi infrastruktur pendukung seperti aturan-aturan, wewenang, mekanisme dan sistem pendanaan masing-masing lembaga pada setiap tingkatan. Hal tersebut senada dengan pendapat Iner dan Page dalam Uphoff (2000) yang menyatakan bahwa kelembagaan adalah tata cara dan prosedur yang telah diciptakan untuk mengatur hubungan antara manusia yang berkelompok dalam suatu kelompok kemasyarakatan.

Rehabilitasi Lahan dan Konservasi Tanah (RLKT) adalah upaya manusia untuk memperbaiki, meningkatkan dan mempertahankan kondisi lahan agar dapat berfungsi secara optimal, baik sebagai unsur produksi, media pengatur tata air maupun sebagai unsur perlindungan alam dan lingkungan (RRL,1993). Upaya Rehabilitasi Lahan dan Konservasi Tanah merupakan kegiatan utama dan strategis dalam pengelolaan DAS untuk menjamin kelestarian Daerah Aliran Sungai (DAS) .

Menurut Departemen Kehutanan (2000), DAS diklasifikasikan menjadi: DAS lokal (DAS yang secara utuh berada di satu daerah kabupaten), DAS regional (DAS yang letaknya secara geografis melewati lebih dari satu kabupaten dan DAS nasional (DAS yang letaknya secara geografis melewati lebih dari satu propinsi). Disamping penggolongan di atas di dalam pelaksanaan Inpres Penghijauan dikenal istilah mikro DAS sebagai satuan Unit Terkecil Pelaksanaan Penghijauan (UTPP).

Menurut Asdak (1995) dalam mempelajari ekosistem DAS, maka DAS dapat dibagi menjadi daerah hulu, tengah, dan hilir. Dalam satuan DAS, harus disadari bahwa setiap wilayah kabupaten adalah bagian dari DAS tersebut, sehingga mempunyai kontribusi langsung terhadap dampak pengelolaan yang dilakukan pada DAS. Karena itu dalam penerapan otonomi perlu dilakukan negosiasi-negosiasi, tidak saja antar daerah, tetapi juga lintas fungsi. Demikian juga negosiasi yang berhubungan dengan kewenangan, sehingga diperoleh kesepakatan mana yang merupakan aset nasional dan mana yang merupakan aset daerah. Sebagai aset nasional tidak semua sumberdaya alam menjadi hak pengelolaan daerah. Sumberdaya alam yang merupakan aset nasional haruslah dilihat sebagai suatu entity, suatu kesatuan tidak terpisah-pisah, meskipun berada pada lintas batas administrasi atau lintas batas daerah. Sebagai aset nasional, sumberdaya alam tidak saja sebagai penghasil devisa, tetapi harus dipikirkan kelestariannya (Utomo, 2001). 
Kebijakan RLKT sebelum otonomi daerah dilaksanakan secara sentralistik (top down) dengan pendekatan lebih ke arah fisik dan terfokus pada wilayah hulu. Namun sejak dikeluarkannya UU No. 22 Tahun 1999 yang diperbaharui dengan UU No. 32 Tahun 2004 tentang Pemerintah Daerah, UU No. 25 Tahun 1999 yang diperbaharui dengan UU No. 33 Tahun 2004 tentang Perimbangan Keuangan Antara Pemerintah Pusat dan Daerah dan PP. No. 25 Tahun 2000 tentang Kewenangan Pemerintah dan Kewenangan Propinsi sebagai Daerah Otonom, maka kelembagaan Rehabilitasi Lahan dan Konservasi Tanah mengalami restrukturisasi, sebab berdasarkan kebijakan tersebut kewenangan pengelolaan dan pemanfaatan sumberdaya alam (termasuk kewenangan penyelenggaraan Rehabilitasi Lahan dan Konservasi Tanah) akan diserahkan kepada daerah kabupaten.

Permasalahan yang muncul setelah diberlakukannya otonomi daerah adalah pengelolaan sumberdaya alam yang ada dalam suatu DAS dilakukan secara terfragmentasi. Masing-masing daerah mengelola sendiri-sendiri sumberdaya alam yang ada di daerahnya. Pengelolaan sumberdaya alam sering tidak diimbangi dengan upaya konservasi, kegiatan konservasi sering tidak menjadi kegiatan yang mendapat prioritas di daerah.

Kegiatan rehabilitasi lahan dan konservasi tanah dalam suatu DAS harus dilakukan secara terpadu dan menyeluruh. Selama ini belum ada koordinasi dan sinkronisasi dalam program, pelaksanaan dan monitoring serta evaluasinya. Untuk menjamin kelestarian DAS, sinkronisasi program, implementasi dan pemantauan perlu dilaksanakan di semua tingkatan, dari tingkat Unit Terkecil Pelaksanaan Penghijauan (UTPP) sampai tingkat propinsi. Untuk itu diperlukan Badan Koordinasi di masingmasing tingkatan tersebut. Di beberapa tempat mungkin telah terbentuk, tetapi dalam penerapan otonomi daerah, koordinasi tersebut perlu diefektifkan dan komitmennya perlu ditingkatkan (Nugroho dkk, 2000).

Tujuan yang diharapkan dari kajian ini adalah mengumpulkan informasi mengenai kelembagaan (jenis dan mekanisme kerja serta tata nilai) yang ada dalam penyelenggraan RLKT pada tingkat Mikro DAS, kabupaten dan propinsi di era otonomi daerah.

Sasaran dari kajian kelembagaan RLKT pada tingkat Mikro DAS/Kabupaten dan Propinsi adalah :

1. Mengetahui dan mengidentifikasi lembaga-lembaga yang fungsional terlibat dalam kegiatan RLKT

2. Mengetahui mekanisme kerja lembaga dalam penyelenggaraan RLKT serta permasalahan yang dihadapi

3. Mengetahui sejauhmana koordinasi lembaga yang terkait dan tata nilai dalam penyelenggaraan RLKT

4. Merumuskan penyempurnaan mekanisme kerja lembaga yang terkait dengan penyelenggaraan RLKT

\section{METODE PENELITIAN}

A. Lokasi Kajian

DAS Progo memiliki luas 268.400 ha, terbagi habis ke dalam 5 sub DAS dan terdiri dari 72 kecamatan dari 9 kabupaten di wilayah Propinsi Jawa Tengah dan Daerah Istimewa Yogyakarta. Wilayah DAS Progo dapat dilihat pada Tabel 1 berikut ini :

\footnotetext{
Kelembagaan Rehabilitasi Lahan dan Konservasi ......(Sulistiya Ekawati dkk)
} 
Tabel 1. Wilayah Daerah DAS Progo

Table 1. The Area of Progo Watershed

\begin{tabular}{|l|l|r|l|}
\hline $\begin{array}{c}\text { No } \\
\text { No }\end{array}$ & \multicolumn{1}{|c|}{$\begin{array}{c}\text { Sub DAS Watershed } \\
\text { Sub }\end{array}$} & $\begin{array}{c}\text { Luas (ha) } \\
\text { Wide }(h a)\end{array}$ & \multicolumn{1}{|c|}{$\begin{array}{c}\text { Kabupaten } \\
\text { Regency }\end{array}$} \\
\hline 1. & Progo Hulu & 30.906 & Temanggung \\
\hline 2. & Elo & 56.989 & $\begin{array}{l}\text { Kodya Magelang, Magelang, } \\
\text { Temanggung, Semarang }\end{array}$ \\
\hline 3. & Tangsi & 46.401 & Magelang, Temanggung, Wonosobo \\
\hline 4. & Progo Hilir & 73.989 & Kulon Progo, Bantul, Sleman, Magelang \\
\hline 5. & Blongkeng Ds & 29.456 & Magelang, Boyolali \\
\hline
\end{tabular}

Sumber : BRLKT SOP, 2001

Lokasi kajian dilaksanakan pada tiga kategori DAS, yaitu DAS yang melewati satu kabupaten (DAS lokal), DAS antar kabupaten (DAS regional) dan DAS antar propinsi (DAS nasional).

Tabel 2. Lokasi Kajian Berdasarkan Tingkatan DAS

Table. Research Area Based on Watershed Level

\begin{tabular}{|l|l|l|l|}
\hline $\begin{array}{l}\text { No } \\
\text { No }\end{array}$ & Kategori DAS & $\begin{array}{l}\text { DAS } \\
\text { Watershed }\end{array}$ & $\begin{array}{l}\text { Wilayah Administrasi } \\
\text { Administration area }\end{array}$ \\
\hline 1. & Satu kabupaten/UTPP & Sub DAS Progo Hulu & Temanggung \\
\hline 2. & Lintas kabupaten & Sub DAS Elo, Tangsi & Magelang, Temanggung \\
\hline 3. & Lintas Propinsi & DAS Progo & $\begin{array}{l}\text { Kulon Progo, } \\
\text { Temanggung, Magelang }\end{array}$ \\
\hline
\end{tabular}

\section{B. Pengumpulan Data}

Kajian kelembagaan RLKT pada Tingkat Mikro DAS, Kabupaten dan Propinsi dilaksanakan dengan pendekatan partisipatif, dengan melakukan diskusi kelompok (focus group discusion) dan indepth interview. Diskusi kelompok dilakukan pada kelompok tani pada masing-masing desa terpilih. Indepth interview dilakukan pada pejabat instansi terkait, kepala desa/dusun, ketua kelompok tani dan koordinator Himpunan Petani Pemakai Air.

Pada masing-masing bagian DAS, diambil 3 desa yang mewakili masyarakat petani daerah hulu (pelaku RLKT), daerah tengah (pelaku RLKT/pengguna air) dan hilir (pengguna air/terkena banjir). Pada masing-masing desa diambil 20 petani. Perincian lengkap desa-desa yang menjadi obyek kajian adalah :

1. Masyarakat hulu DAS (pelaku RLKT)

- Desa Kataan, Kecamatan Ngadirejo, Kabupaten Temanggung

- Desa Bansari, Kecamatan Bansari, Kabupaten Temanggung

- Desa Pagersari, Kecamatan Tlogomulyo, Kabupaten Temanggung

2. Masyarakat tengah DAS (pelaku RLKT/pengguna air)

- Desa Kalisalak, Kecamatan Salaman, Kabupaten Magelang

- Desa Sutopati, Kecamatan Kajoran, Kabupaten Magelang

- Desa Borobudur, Kecamatan Borobudur, Kabupaten Magelang

3. Masyarakat hilir DAS (pengguna air/terkena banjir)

- Desa Cerme, Kecamatan Panjatan, Kabupaten Kulon Progo

- Desa Gotakan, Kecamatan Panjatan, Kabupaten Kulon Progo

- Desa Kanoman, Kecamatan Panjatan, Kabupaten Kulon Progo 


\section{Analisis Data}

Kajian Kelembagaan RLKT pada Tingkat Mikro DAS, Kabupaten dan Propinsi di Era Otonomi Daerah dibatasi, untuk mengidentifikasi semua stakeholder yang terlibat dalam penyelenggaraan RLKT dan mekanisme kerjanya. Data yang terkumpul dianalisis dengan metode diskriptif kualitatif yang diperkuat oleh data dan informasi pendukung.

\section{HASIL DAN PEMBAHASAN}

\section{A. Organisasi yang Terkait dalam Penyelenggaraan RLKT}

Dalam kajian ini, organisasi yang terkait dalam kelembagaan RLKT dibedakan menurut kategori DAS dan kategori masyarakat. Dari hasil survei diperoleh data bahwa organisasi yang terkait dalam penyelenggaraan RLKT pada kategori DAS dapat dilihat pada Tabel 3 berikut :

Tabel 3. Organisasi Terkait dengan Penyelenggaraan Rehabilitasi Lahan dan Konservasi Tanah pada kategori DAS

Table 3. Organization involved with Management of Land Rehabilitation and Conservation on Category of Watershed

\begin{tabular}{|c|c|c|c|}
\hline $\begin{array}{l}\text { No } \\
\text { No }\end{array}$ & $\begin{array}{l}\text { Kategori DAS } \\
\text { Watershed } \\
\text { category }\end{array}$ & $\begin{array}{l}\text { Fungsi } \\
\text { Pengelolaan } \\
\text { Function of } \\
\text { management }\end{array}$ & $\begin{array}{l}\text { Organisasi Terkait } \\
\text { Involed organization }\end{array}$ \\
\hline \multirow[t]{3}{*}{1} & \multirow[t]{3}{*}{$\begin{array}{l}\text { DAS Nasional } \\
\text { (lintas } \\
\text { propinsi) }\end{array}$} & Perencanaan & $\begin{array}{l}\text { Bappeda Propinsi, BPDAS SOP, Dinas Pertanian } \\
\text { Propinsi, Dinas Kehutanan Propinsi, Dinas Pengelolaan } \\
\text { Sumberdaya Air, Perum Perhutani }\end{array}$ \\
\hline & & Pelaksanaan & $\begin{array}{l}\text { Dinas Kehutanan Propinsi, Dinas Pertanian Propinsi, } \\
\text { Dinas Pertambangan dan Energi, Perum Perhutani, } \\
\text { Dinas Pengelolaan Sumberdaya Air }\end{array}$ \\
\hline & & Monev & $\begin{array}{l}\text { BPDAS SOP, Bappeda Propinsi, Bapedalda Propinsi, } \\
\text { Balai Pengelolaan Sumberdaya Air }\end{array}$ \\
\hline \multirow[t]{3}{*}{2.} & \multirow[t]{3}{*}{$\begin{array}{l}\text { DAS regional } \\
\text { (DAS lintas } \\
\text { kabupaten) }\end{array}$} & Perencanaan & $\begin{array}{l}\text { Bappeda Propinsi, BPDAS SOP, Dinas Pertanian } \\
\text { Propinsi, Dinas Kehutanan Propinsi, Dinas Pengelolaan } \\
\text { Sumberdaya Air, Perum Perhutani }\end{array}$ \\
\hline & & Pelaksanaan & $\begin{array}{l}\text { Dinas Kehutanan Propinsi, Dinas Pertanian Propinsi, } \\
\text { Dinas Pertambangan dan Energi, Perum Perhutani, } \\
\text { Dinas Pengelolaan Sumberdaya Air }\end{array}$ \\
\hline & & Monev & $\begin{array}{l}\text { BPDAS SOP, Bappeda Propinsi, Bapedalda Propinsi, } \\
\text { Balai Pengelolaan Sumberdaya Air }\end{array}$ \\
\hline \multirow[t]{3}{*}{3} & $\begin{array}{l}\text { DAS lokal } \\
\text { (DAS satu } \\
\text { kabupaten) }\end{array}$ & Perencanaan & $\begin{array}{l}\text { Bappeda Kabupaten, Dinas Kehutanan } \\
\begin{array}{l}\text { Dinas Pertanian Kabupaten, } \\
\text { Kabupaten, Perhutani }\end{array} \\
\end{array}$ \\
\hline & & Pelaksanaan & $\begin{array}{l}\text { Dinas } \quad \text { Kehutanan } \quad \text { Kabupaten, Dinas Pertanian } \\
\text { Kabupaten, Dinas Pengairan Kabupaten, Perhutani }\end{array}$ \\
\hline & & Monev & $\begin{array}{l}\text { Bappeda Kabupaten, Dinas Pertanian, Dinas Kehutanan, } \\
\text { Dinas Pengairan Kabupaten, Perhutani }\end{array}$ \\
\hline \multirow[t]{3}{*}{4.} & Mikro DAS & Perencanaan & $\begin{array}{l}\text { Kelompok Tani, Pemerintahan Desa, Pemerintahan } \\
\text { Kecamatan, Cabang Dinas Kehutanan, Cabang Dinas } \\
\text { Pertanian }\end{array}$ \\
\hline & & Pelaksanaan & $\begin{array}{l}\text { Kelompok Tani, Cabang Dinas Kehutanan, Cabang } \\
\text { Dinas Pertanian }\end{array}$ \\
\hline & & Monev & $\begin{array}{l}\text { Cabang Dinas Kehutanan, Cabang Dinas Pertanian, } \\
\text { LSM }\end{array}$ \\
\hline
\end{tabular}


Pada Tabel 3 terlihat bahwa penyelenggaraan Rehabilitasi Lahan dan Konservasi Tanah pada kategori DAS nasional dan regional dilakukan oleh Pemerintahan Propinsi, sedangkan penyelenggaraan Rehabilitasi Lahan dan Konservasi Tanah pada kategori DAS lokal dan mikro DAS dilakukan oleh Pemerintahan Kabupaten.

Organisasi yang terlibat pada penyelenggaraan Rehabilitasi Lahan dan Konservasi Tanah pada kategori DAS nasional dan DAS regional sama, padahal sebenarnya berdasarkan PP No. 25 tahun 2000, semua yang berkaitan dengan kewenangan lintas propinsi menjadi kewenangan pusat dan urusan yang berkaitan dengan kewenangan lintas kabupaten menjadi kewenangan propinsi.

Kondisi tersebut akan menimbulkan terjadinya tumpang-tindih kewenangan dan penyelenggaraan kegiatan. Implikasi logis dari hal tersebut adalah : 1) duplikasi kegiatan antara pusat dan daerah, 2) tidak sinkronnya kegiatan pada level DAS yang berbeda, 3) koordinasi yang tidak optimal dan 4) pemborosan anggaran. Oleh karena itu perlu disesuaikan organisasi penyelenggara RLKT di lapangan sesuai dengan perundang-undangan yang berlaku, sehingga tidak terjadi tumpang tindih kewenangan.

Organisasi yang berhubungan dengan kelembagaan RLKT pada kategori masyarakat dapat dilihat pada Tabel 4 berikut :

Table 4. Organisasi yang Terkait dalam Penyelenggaraan Rehabilitasi Lahan dan Konservasi Tanah pada Kategori Masyarakat

Table 4. Organization involved with Management of land Rehabilitation and Conservation on Category of Community

\begin{tabular}{|l|l|l|l|}
\hline $\begin{array}{l}\text { No } \\
\text { No }\end{array}$ & $\begin{array}{l}\text { Kategori Masyarakat } \\
\text { Community category }\end{array}$ & \multicolumn{1}{|c|}{$\begin{array}{c}\text { Organisasi Terkait } \\
\text { Involved Organization }\end{array}$} & $\begin{array}{l}\text { Fungsi pengelolaan } \\
\text { Function of mana- } \\
\text { gement }\end{array}$ \\
\hline 1. & $\begin{array}{l}\text { Masyarakat hulu } \\
\text { (pelaku RLKT) }\end{array}$ & $\begin{array}{l}\text { Kelompok Tani, Pemerin } \\
\text { tah Desa, Dinas terkait, } \\
\text { LSM }\end{array}$ & $\begin{array}{l}\text { Perencanaan, } \\
\text { pelaksanaan, monev }\end{array}$ \\
\hline 2. & $\begin{array}{l}\text { Masyarakat tengah } \\
\text { (masyarakat pelaku } \\
\text { RLKT dan pengguna } \\
\text { air) }\end{array}$ & $\begin{array}{l}\text { Kelompok Tani, } \\
\text { Pemerintah Desa, Dinas } \\
\text { terkait, P3A, LSM }\end{array}$ & $\begin{array}{l}\text { Perencanaan, } \\
\text { pelaksanaan, monev }\end{array}$ \\
\hline 3. & $\begin{array}{l}\text { Masyarakat hilir } \\
\text { (masyarakat pengguna } \\
\text { air dan terkena banjir) }\end{array}$ & $\begin{array}{l}\text { Kelompok } \\
\text { Pemerintah Desa, Dinas } \\
\text { terkait, P3A, LSM, } \\
\text { Kesbanglinmas }\end{array}$ & $\begin{array}{l}\text { Perencanaan, } \\
\text { pelaksanaan, monev }\end{array}$ \\
\hline
\end{tabular}

Pada Tabel 4 di atas terlihat bahwa organisasi yang terkait dalam penyelenggaraan RLKT pada masing-masing kategori masyarakat adalah Kelompok Tani, Pemerintah Desa, Dinas terkait dan LSM, kecuali pada masyarakat pengguna air terkait dengan organisasi P3A dan masyarakat terkena banjir terkait dengan organisasi Kesbanglinmas (Kantor Kesatuan Bangsa dan Perlindungan Masyarakat)

Pada ketiga kategori masyarakat terlihat bahwa sebenarnya organisasi terkait dengan kegiatan RLKT hampir sama antara masyarakat hulu, masyarakat tengah dan hilir, demikian pula fungsi-fungsi pengelolaan yang dilakukan. Padahal seharusnya masing-masing kategori masyarakat mempunyai suatu organisasi tertentu yang mengemban tugas tertentu pula, sehingga fungsi-fungsi manajemen (seperti perencanaan, pelaksanaan dan pengawasan) dapat berjalan baik. 


\section{B. Mekanisme Kerja}

Mekanisme kerja antar lembaga dalam penyelenggaraan RLKT tidak terlepas dari konsep pengelolaan DAS, yaitu meliputi perencanaan, pelaksanaan dan monev. Namun belum ada acuan yang jelas dan khusus dari peraturan perundangan yang berkaitan dengan pengelolaan DAS. Peraturan dan perundangan yang ada hanya mengatur kewenangan dan tanggung jawab pemerintah daerah secara umum. Implikasi dari belum adanya mekanisme kerja yang mantap dan terstruktur tersebut membuat koordinasi antar institusi belum optimal. Belum adanya landasan hukum yang jelas dan terarah membuat pengelolaan DAS berjalan dalam keproyekan-keproyekan, padahal stakeholders yang terlibat banyak sekali, belum ada satu lembagapun yang ditunjuk untuk bertangung jawab untuk mengelolanya. Pengelolaan DAS yang berjalan selama ini adalah sebagai berikut.

1. Perencanaan RLKT

Perencanaan kegiatan Rehabilitasi Lahan dan Konservasi Tanah di tingkat mikro DAS disusun secara partisipatif oleh petani melalui kelompok tani dengan bimbingan penyuluh setempat dan disetujui oleh Kepala Desa. Dari perencanaan tingkat desa, kemudian dibahas di dalam Rapat Koordinasi Pembangunan di tingkat kecamatan untuk selanjutnya dibahas di Dinas terkait.

Perencanaan kegiatan Rehabilitasi Lahan dan Konservasi Tanah untuk DAS kabupaten disusun oleh masing-masing dinas, kemudian dibahas di Rapat Koordinasi Pembangunan Kabupaten yang dikoordinir oleh Bappeda. Bappeda selama ini hanya berfungsi sebagai fasilitator dan kompilator dalam perencanaan, padahal seharusnya Bappeda berfungsi sebagai penyusun grand design kabupaten, bukan hanya menggabungkan rencana-rencana yang disusun oleh masing-masing dinas. Bappeda seharusnya mempunyai grand design yang dijadikan acuan oleh masing-masing dinas.

Perencanaan kegiatan Rehabilitasi Lahan dan Konservasi Tanah di tingkat DAS nasional disusun oleh masing-masing dinas secara sektoral. Bappeda tingkat Propinsi yang mengkompilasi perencanaan yang disusun oleh masing-masing dinas propinsi. Sejauh ini belum ada upaya dari Bappeda Propinsi untuk membuat grand design di tingkat propinsi. Grand design yang selama ini disusun oleh Bappeda Propinsi bersifat makro. Di era otonomi daerah, masing-masing daerah (kabupaten) menerjemahkan grand design tersebut dengan menyusun perencanaan detilnya di kabupaten berdasarkan kepentingannya masing-masing.

Salah satu perencanaan yang disusun dalam satuan ekosistem DAS adalah Pola Rehabilitasi Lahan dan Konservasi Tanah DAS Progo (perencanaan jangka panjang) dan Rencana Teknik Lapangan Rehabilitasi Lahan dan Konservasi Tanah (RTL RLKT) DAS Progo (perencanaan jangka menengah) yang disusun oleh Balai Pengelolaan Daerah Aliran Sungai Serayu Opak Progo (BPDAS SOP). Permasalahannya adalah, tidak semua daerah dan semua sektor menjadikan rencana tersebut sebagai acuan. Perencanaan RLKT di masing-masing kabupaten disusun berdasarkan hamparan, belum mengacu pada konsep DAS. Konsep DAS yang disusun oleh BPDAS melalui Pola RLKT DAS Progo dan RTL RLKT DAS Progo sulit diaplikasikan di masing-masing kabupaten, karena kabupaten belum cukup memahami konsep DAS sebagai satuan pengelolaan, disamping itu sejak otonomi daerah isu pemerataan menjadi topik yang lebih penting. Kegiatan RLKT dengan dasar Sub DAS akan membuat suatu kegiatan terkonsentrasi pada daerah tertentu. Hal ini merupakan alasan mengapa kegiatan RLKT dilaksanakan berdasarkan hamparan.

Kelembagaan Rehabilitasi Lahan dan Konservasi ......(Sulistiya Ekawati dkk) 
Belum ada koordinasi yang baik antar kabupaten maupun antar propinsi dalam penyusunan perencanaan DAS Progo. Masing-masing kabupaten menyusun perencanaannya sendiri pada masing-masing sektor.

2. Pelaksanaan

Pelaksanaan kegiatan RLKT pada tingkat mikro DAS, kabupaten dan propinsi mengacu pada perencanaan yang disusun oleh Dinas masing-masing. Satuan pelaksanaan kegiatan RLKT pada masing-masing kabupaten adalah hamparan, kecuali untuk kegiatan yang didanai oleh BPDAS (Proyek South Java Flood Control dan proyek lain) didasarkan pada satuan Sub DAS.

Masing-masing kabupaten dan masing-masing sektor melaksanakan kegiatan RLKT berdasarkan kepentingan masing-masing. Sebagai contoh di Kabupaten Temanggung dan Magelang lebih mengutamakan kegiatan konservasi tanah vegetatif, karena selain dapat mengendalikan erosi, juga langsung memberikan manfaat bagi peningkatan pendapatan petani setelah tanaman tersebut berproduksi. Kabupaten Temangung dan Magelang yang berada di hulu dan tengah DAS Progo yang seharusnya melakukan konservasi yang bertujuan mengendalikan erosi (gully plug, dam penahan/pengendali, sedimen trap) justru kurang merespon kegiatan konservasi sipil teknis. Kedua kabupaten tersebut belum memikirkan sedimentasi pada daerah hilir. Sebaliknya di Kabupaten Kulon Progo yang kadangkadang terkena banjir dan tanah longsor justru yang lebih banyak melakukan kegiatan RLKT sipil teknis (terasering, dam penahan/pengendali, gully plug dan sebagainya) maupun vegetatif.

3. Monitoring dan Evaluasi

Monitoring kegiatan RLKT pada mikro DAS dan DAS lokal dilakukan oleh Dinas terkait, metode yang digunakan adalah dengan membandingkan target kegiatan yang ditetapkan pada anggaran yang ada dengan realisasi pelaksanaan di lapangan. Jadi kegiatan monitoring masih bersifat on site, belum bersifat off site, karena dasar pelaksanaan kegiatan RLKT yang dilakukan adalah hamparan.

Monitoring kegiatan RLKT DAS regional, sebenarnya merupakan tugas dari Dinas Kehutanan Propinsi, Bappeda Propinsi, Dinas Pengairan Propinsi dan BPDAS Serayu Opak Progo, tetapi dalam kenyataannya instansi tersebut tidak mempunyai kewenangan di kabupaten. Menurut UU No. 22 Tahun 1999 yang diperbaharui dengan UU No. 32 tahun 2004, pemerintah daerah dalam menyelenggarakan urusan pemerintahan memiliki hubungan dengan pemerintah pusat dan dengan pemerintah daerah lainnya. Hubungan tersebut meliputi hubungan kewenangan, keuangan, pelayanan umum, pemanfaatan sumberdaya alam dan sumberdaya lain. Menurut PP No 25 Tahun 2000, kewenangan yang bersifat lintas kabupaten, termasuk dalam pengendalian lingkungan hidup (diantaranya RLKT) menjadi kewenangan propinsi.

Mekanisme kerja pengelolaan DAS yang baik dapat dilihat pada Tabel 5 . Pada kategori mikro DAS, perencanaan disusun dari bawah (bottom up) oleh kelompok tani, dengan persetujuan dari pemerintah desa dan kecamatan untuk diajukan ke cabang dinas. Sebagai pelaksana sekaligus monev kegiatan RLKT adalah cabang dinas dan kelompok tani.

Pada kategori DAS lokal (dalam kabupaten), grand design disusun oleh Bappeda kabupaten dengan berkoordinasi dengan BPDAS dan BPSDA, selanjutnya masingmasing dinas di kabupaten menjabarkan grand design tersebut dalam perencanaan di sektornya masing-masing. Sebagai pelaksana kegiatan RLKT adalah dinas kabupaten dan Perum Perhutani. Fungsi monev dilakukan oleh lembaga yang menyusun rencana. 
Pada kategori DAS regional (lintas kabupaten), grand design disusun oleh Bappeda propinsi. BPSDA, BPDAS dan dinas-dinas propinsi menyusun perencanaan di sektornya masing-masing dengan berpegang pada grand design yang ada. Sebagai pelaksana kegiatan RLKT adalah dinas kabupaten dan Perum Perhutani. Fungsi monev dilakukan oleh lembaga yang menyusun rencana.

Pada tataran DAS nasional (lintas propinsi), grand design perencanaan dilakukan oleh Bappenas, masing-masing departemen menyusun perencanaan di sektornya masing-masing dengan acuan grand design dari Bappenas. Perencanaan di tingkat pusat oleh masing-masing departemen/lembaga non departemen dijabarkan menjadi perencanaan di tingkat propinsi oleh dinas-dinas propinsi, BPSDA maupun BPDAS. Sebagai pelaksana kegiatan RLKT adalah dinas di propinsi dan kabupaten dan Perum Perhutani. Sedangkan fungsi monev dilakukan oleh lembaga yang menyusun rencana.

\section{Koordinasi}

Koordinasi dalam penyelenggaraan RLKT antar kabupaten maupun intern kabupaten merupakan masalah penting di era otonomi daerah, karena penyelenggaraan RLKT tidak hanya berdampak pada wilayah kabupaten yang bersangkutan akan tetapi juga berdampak pada wilayah kabupaten lainnya dalam satuan DAS. Hasil pengumpulan data menunjukkan bahwa masing-masing sektor dan wilayah belum melakukan koordinasi dalam kegiatan RLKT. Koordinasi antar kabupaten dalam pengelolaan DAS Progo selama ini hanya berujud seminar monev DAS Progo dan Pelatihan tentang Perencanaan dan Monev DAS Progo yang diadakan oleh BP2TPDAS IBB dan Lokakarya Pengelolaan DAS yang fasilitasi oleh BPDAS OPS.

Koordinasi intern kabupaten dilaksanakan melalui Rapat Koordinasi Pembangunan (Rakorbang) yang dikoordinir oleh Bappeda. Tim Koordinasi/Tim Konsultatif untuk kegiatan Rehabilitasi Hutan dan Lahan sudah terbentuk, tetapi aplikasi lapangan tidak berjalan. Koordinasi antara Propinsi Jawa Tengah dan DIY dilakukan melalui rapat koordinasi yang diikuti oleh Dinas Kehutanan dan Perkebunan DIY, Dinas Kehutanan Jawa Tengah, Bappeda dan Bapedalda Propinsi untuk membahas keterpaduan tata ruang dan kegiatan yang terkait dengan lingkungan hidup.

Karena kurangnya koordinasi antar sektor dan antar wilayah, ada beberapa duplikasi kegiatan. Sebagai contoh Dinas Pertanian melakukan kegiatan konservasi di tanah milik, demikian juga Dinas Kehutanan. Salah satu indikator tercapainya koordinasi yang baik adalah tidak terjadinya tumpang tindih kegiatan, masing-masing sektor saling melengkapi untuk mencapai suatu sasaran kegiatan.

Koordinasi menurut Henry Fayol (1992) berarti mengikat bersama, menyatukan dan menselaraskan semua kegiatan dan usaha. Prinsip koordinasi menerangkan bahwa pelaksanaan organisasi itu efektif apabila semua orang dan sumber disinkronkan, diseimbangkan dan diberikan pengarahan (Hicks, 1967 dalam Sutarto,1998). Agar koordinasi antar wilayah dan antar sektor dapat berjalan dengan baik, perlu dibentuk suatu payung hukum yang jelas, yang dapat mengikat dan menselaraskan semua stakeholders untuk bersama-sama sepakat mencapai satu tujuan, yaitu melakukan rehabilitasi lahan dan konservasi tanah.

\section{Tata Nilai}

Tata nilai dapat dinyatakan sebagai keyakinan relatif masyarakat tentang yang baik dan yang buruk, yang benar dan yang salah, kepada apa yang seharusnya ada dan 
seharusnya tidak ada. Nilai-nilai memberikan sumbangan yang berarti untuk pembentukan suatu pandangan. Dengan mengetahui tata nilai di suatu masyarakat dalam penyelenggaraan RLKT, dapat dijadikan bahan untuk meramu norma yang kemudian ditetapkan sebagai pedoman berperilaku. (Deverger, 1982 dalam Donie, 2002). Untuk menyusun kelembagaan RLKT, diperlukan pengetahuan dan pemahaman mengenai pandangan-pandangan yang berkembang dalam masyarakat. Ada dua hal yang perlu diketahui dalam tata nilai pada kegiatan RLKT, yaitu pandangan masyarakat terhadap RLKT dan komitmennya terhadap pelaksanaan kegiatan RLKT. Pandangan masyarakat hulu, tengah dan hilir DAS terhadap RLKT dapat dilihat pada Tabel 6 berikut :

Tabel 6. Pandangan dan Manfaat Kegiatan RLKT bagi Masyarakat

Table 6. View and Benefit of Land Rehabilitation and Conservation for Community

\begin{tabular}{|l|l|l|l|}
\hline $\begin{array}{l}\text { No } \\
\text { No }\end{array}$ & $\begin{array}{c}\text { Kategori Masyarakat } \\
\text { Community category }\end{array}$ & $\begin{array}{c}\text { Pandangan } \\
\text { Masyarakat } \\
\text { Point of View }\end{array}$ & $\begin{array}{c}\text { Manfaat Kegiatan RLKT } \\
\text { Benefit of Land Rehabilitation and } \\
\text { Conservation for Community }\end{array}$ \\
\hline 1. & Masyarakat hulu & Positip & $\begin{array}{l}\text { Mengurangi erosi, menyuburkan } \\
\text { tanah, mengurangi pupuk yang } \\
\text { hanyut }\end{array}$ \\
\hline 2. & Masyarakat tengah & Positip & $\begin{array}{l}\text { Ketersediaan air irigasi, mengurangi } \\
\text { erosi, menyuburkan tanah dan } \\
\text { mengurangi pupuk yang hanyut }\end{array}$ \\
\hline 3. & Masyarakat hilir & Positip & Ketersediaan air irigasi \\
\hline
\end{tabular}

Masyarakat di hulu, tengah dan hilir DAS Progo umumnya berpandangan positip terhadap kegiatan RLKT, karena mereka tahu manfaat dari kegiatan RLKT. Masyarakat juga sudah memahami bahwa banjir, tanah longsor dan kekeringan merupakan dampak yang ditimbulkan dari kurang baiknya konservasi tanah dan air.

Kejadian banjir di DAS Progo tidak begitu terasa bagi masyarakat di hilir. Kejadian banjir hanya dirasakan di Daerah Panjatan. Banjir di daerah tersebut bukan disebabkan kiriman air dari hulu sungai, tetapi karena naiknya tinggi muka air laut, sehingga air dari Sungai Progo menggenangi daerah di sekitar muara. Komitmen pemerintah dalam kegiatan RLKT dapat dilihat pada ada tidaknya kelembagaan yang mengurusi RLKT dan ada tidaknya Peraturan Daerah tentang RLKT. Pada masingmasing kabupaten kajian terdapat lembaga yang mengurusi RLKT, yaitu adanya Seksi Konservasi Tanah di Dinas Kehutanan dan Perkebunan Kabupaten Temanggung, Kepala Sub Dinas Pengembangan Rehabilitasi Lahan dan Perlindungan Tanaman pada Dinas Pertanian Kabupaten Magelang dan Seksi Rehabilitasi dan Konservasi Lahan pada Dinas Pertanian dan Kelautan Kabupaten Kulon Progo. Masing-masing kabupaten pada lokasi kajian belum mempunyai Perda tentang RLKT.

Parameter lain yang dapat dilihat untuk mengukur komitmen masyarakat dan pemerintah dalam kegiatan RLKT adalah kesediaan untuk membiayai kegiatan RLKT. Saat ini berkembang wacana bahwa biaya kegiatan RLKT tidak sepenuhnya menjadi tangungjawab masyarakat hulu, tetapi masyarakat tengah dan hilir juga ikut bertangungjawab. Salah satu konsep yang diajukan adalah dengan cost sharing, dimana daerah tengah dan hilir sebagai pengambil manfaat dari pelaksanaan kegiatan RLKT di daerah hulu diminta untuk membiayai pelaksanaan RLKT di hulu. Namun sebenarnya hal ini tidak selalu demikian, mengingat masyarakat hilir selama ada yang merasa dirugikan dan mereka sudah mengeluarkan biaya yang tidak sedikit untuk mengatasi 
bencana seperti banjir dan tanah longsor. Disamping itu masyarakat hilir juga belum merasakan manfaat secara langsung dari kegiatan RLKT di hulu. Masyarakat hilir dan tengah tidak selalu berada pada posisi diuntungkan, juga tidak selalu mereka pada posisi dirugikan. Masing-masing bersifat spesifik tergantung dari karakteristik DAS, oleh karena itu dalam konsep cost sharing, karakteristik ini menjadi pertimbangan utama. Walaupun masing-masing kategori masyarakat mempunyai pandangan positif terhadap RLKT, tetapi karena beberapa alasan di atas, mereka tidak bersedia untuk cost sharing.

Seperti halnya masyarakat, masing-masing kabupaten, baik daerah hulu, tengah dan hilir DAS belum bersedia untuk cost sharing dan masih mengharapkan sebagian besar dana untuk RLKT berasal dari pemerintah pusat.

Tabel 7. Kesediaan Pembiayaan Penyelenggaraan RLKT

Table 7. Willingness of Land Rehabilitation and Conservation Funding

\begin{tabular}{|l|c|c|c|}
\hline $\begin{array}{c}\text { No } \\
\text { No }\end{array}$ & $\begin{array}{c}\text { Kabupaten } \\
\text { Regency }\end{array}$ & $\begin{array}{c}\text { Siapa yang mendanai } \\
\text { RLKT } \\
\text { Who is funding } R L K T\end{array}$ & $\begin{array}{c}\text { Kesediaan untuk cost sharing } \\
\text { Willingness to cost sharing }\end{array}$ \\
\hline 1. & Hulu & APBD + Pusat & Tidak mau \\
\hline 2. & Tengah & APBD + Pusat & Tidak mau \\
\hline 3. & Hilir & APBD + Pusat & Tidak mau \\
\hline
\end{tabular}

Berdasarkan tabel di atas jelas kelihatan bahwa, masing-masing daerah belum bersedia untuk melalukan cost sharing. Masing-masing kabupaten masih mengharapkan urusan-urusan konservasi sumberdaya alam mendapat bantuan dari pemerintah pusat. Urusan RLKT kurang mendapat prioritas di pemerintah kabupaten, karena pemerintah kabupaten tidak mempunyai dana yang cukup untuk menyelenggarakan kegiatan RLKT. Disamping itu dampak yang diberikan dari suatu kegiatan RLKT memerlukan waktu yang relatif agak lama. Konsekwensi dari keadaan di atas adalah penyelenggaraan kegiatan RLKT tetap menjadi tangungjawab Pemerintah Pusat.

\section{KESIMPULAN}

\section{A. Kesimpulan}

1. Organisasi yang terlibat dalam penyelenggaraan RLKT pada kategori DAS nasional dan regional sama, dilakukan oleh pemerintah propinsi, sedangkan penyelenggaraan RLKT pada kategori DAS lokal dan mikro DAS dilakukan pemerintah kabupaten. Kondisi tersebut tidak sesuai dengan PP No 25 tahun 2000, sehingga menimbulkan tumpang-tindih kewenangan.

2. Organisasi yang terkait dengan kegiatan RLKT pada masyarakat hulu, tengah dan hilir hampir sama, demikian pula fungsi-fungsi pengelolaan yang dilakukan.

3. Mekanisme kerja lembaga dalam penyelenggaraan RLKT pada level DAS lokal, regional maupun nasional belum berjalan dengan baik. Kegiatan RLKT belum dilaksanakan dalam satuan DAS sebagai satuan pengelolaan.

4. Koordinasi antar lembaga dalam penyelenggaraan RLKT di DAS Progo sudah mulai dirintis, namun demikian aplikasi lapangan belum berjalan dengan baik.

5. Pandangan kabupaten hulu, tengah dan hilir DAS terhadap RLKT adalah baik, karena mereka sebenarnya sudah memahami manfaat dari pelaksanaan kegiatan RLKT.

Kelembagaan Rehabilitasi Lahan dan Konservasi ......(Sulistiya Ekawati dkk) 
Walaupun demikian masyarakat di daerah hulu, tengah dan hilir DAS belum bersedia untuk melakukan sharing dalam pembiayaan RLKT.

6. Mekanisme kerja kelembagaan RLKT yang baik disusun berdasarkan masukan dan kebutuhan dari bawah (bottom up), mulai dari kelompok tani kemudian diformulasikan oleh perencana wilayah sesuai hirarki perencanaan.

\section{B. Saran}

1. Berdasarkan hasil kajian disarankan bentuk organisasi penyelenggaraan RLKT yang dibangun atas dasar skala DAS dan fungsi-fungsi pengelolaan (perencanaan, pelaksanaan dan monev), seperti tampak pada tabel berikut.

\begin{tabular}{|c|c|c|c|c|c|c|}
\hline \multirow{3}{*}{$\begin{array}{l}\text { Katego- } \\
\text { ri DAS }\end{array}$} & \multicolumn{6}{|c|}{ Fungsi-Fungsi Pengelolaan } \\
\hline & \multicolumn{3}{|c|}{ Perencanaan } & \multirow{2}{*}{$\begin{array}{l}\text { Pelak- } \\
\text { sanaan }\end{array}$} & \multirow[t]{2}{*}{ Monitoring } & \multirow[t]{2}{*}{ Evaluasi } \\
\hline & $\begin{array}{c}\text { Perenca- } \\
\text { naan } \\
\text { Makro }\end{array}$ & $\begin{array}{c}\text { Perenca- } \\
\text { naan Meso }\end{array}$ & $\begin{array}{l}\text { Perenca- } \\
\text { naan } \\
\text { Operasi- } \\
\text { onal }\end{array}$ & & & \\
\hline $\begin{array}{l}\text { DAS } \\
\text { nasional }\end{array}$ & Pusat & Pusat & $\begin{array}{l}\text { Kabupa- } \\
\text { ten }\end{array}$ & $\begin{array}{l}\text { Kabupa- } \\
\text { ten }\end{array}$ & $\begin{array}{l}\text { Pusat/Propin } \\
\text { si/ } \\
\text { Kabupaten }\end{array}$ & Pusat \\
\hline $\begin{array}{l}\text { DAS } \\
\text { regional }\end{array}$ & Propinsi & Propinsi & $\begin{array}{l}\text { Kabupa- } \\
\text { ten }\end{array}$ & $\begin{array}{l}\text { Kabupa- } \\
\text { ten }\end{array}$ & $\begin{array}{l}\text { Propinsi/ } \\
\text { Kabupaten }\end{array}$ & Propinsi \\
\hline $\begin{array}{l}\text { DAS } \\
\text { lokal }\end{array}$ & $\begin{array}{l}\text { Kabupa- } \\
\text { ten }\end{array}$ & Kabupaten & $\begin{array}{l}\text { Kabupa- } \\
\text { ten }\end{array}$ & $\begin{array}{l}\text { Kabupa- } \\
\text { ten }\end{array}$ & Kabupaten & Kabupaten \\
\hline $\begin{array}{l}\text { Mikro } \\
\text { DAS } \\
\text { /UTPP }\end{array}$ & $\begin{array}{l}\text { Kabupa- } \\
\text { ten }\end{array}$ & Kabupaten & $\begin{array}{l}\text { Kabupa- } \\
\text { ten }\end{array}$ & $\begin{array}{l}\text { Kabupa- } \\
\text { ten }\end{array}$ & Kabupaten & Kabupaten \\
\hline
\end{tabular}

2. Masing-masing stakeholders perlu melakukan koordinasi dalam kegiatan RLKT. Koordinasi dalam penyelenggaraan RLKT dapat berjalan, jika ada payung hukum yang jelas dan mengikat, sehingga semua pihak yang terlibat dalam kegiatan penyelenggaraan RLKT merasa berkewajiban untuk mematuhinya.

3. Perlu dirumuskan mekanisme cost sharing yang jelas antara daerah hulu, tengah dan hilir, sehingga sumberdana yang menjadi masalah dalam penyelenggaraan RLKT dapat dipecahkan. 


\section{DAFTAR PUSTAKA}

Departemen Kehutanan. 2000. Pedoman Penyelenggaraan Daerah Aliran Sungai. Jakarta.

Donei, S dan Sumaryati. 2002. Laporan Kajian Kelembagaan RLKT . BP2TPDAS-IBB. Solo

Darmawan, D.A. 2001. Analisa Kelembagaan. Paper Diskusi Pengelolaan DAS Terpadu dalam Rangka Otonomi Daerah. Fakultas Kehutanan, Universitas Gajah Mada. Yogyakarta.

Henry, F. 1992. Public Administration and Public Affairs. Edisi ke-5. Pretince Hall International Edition, Inc. New Jersey.

Nugroho, SP, Mastur dan Donie. 2000. DAS merupakan Unit Pengelolaan Sumberdaya Alam Yang Lestari dan Berkeadilan. Ekspose Hasil-Hasil Penelitian BTP DAS Surakarta. Surakarta.

Soekanto, S. 1983. Sosiologi Suatu Pengantar. Yayasan Penerbit Universitas Indonesia. Jakarta

Sutarto. 1998. Dasar-Dasar Organisasi. Gadjah Mada University Press. Yogyakarta.

Uphoff, N. 1986. Local Institutional Development: An Analytical Sourcebook with Cases. Kumarian Press. Connecticut. USA

Utomo, W. 2001. Dilema Penerapan Otonomi Daerah pada Pengelolaan Sumberdaya Alam Lintas Batas Administrasi. Makalah Seminar Nasional Dilema Penerapan Otonomi Daerah dalam Pengelolaan Sumberdaya Alam Berwawasan Lingkungan. Yogyakarta, 9 - 11 Agustus 2001. Program studi Lingkungan. UGM. 